\title{
Cerium oxide nanoparticles induced physio-biochemical, neurochemical, and morphological responses in Cirrhinus mrigala during short term exposure
}

\author{
Kalpesh Swamy ${ }^{a}$, Naveenkumar Chandrashekar ${ }^{\mathrm{b}}$, Raghunandhakumar Subramanian ${ }^{\mathrm{c}}$, Sandya \\ Sukumaran ${ }^{\mathrm{d}}$, Sharath Chandra $\mathrm{SP}^{\mathrm{e}^{*}}$ \\ ${ }^{a}$ Department of Biotechnology, Government Science College, Hassan, Karnataka, India \\ ${ }^{b}$ Department of Biochemistry, Indian Academy Degree College - Autonomous, Bengaluru, Karnataka, India \\ 'Department of Pharmacology, Saveetha Dental College and Hospitals, Saveetha Institute of Medical and Technical Sciences, Chennai, India \\ ${ }^{d}$ Department of Inorganic and Physical Chemistry, Indian Institute of Science, Bangalore, Karnataka, India \\ ${ }^{e}$ Department of Biochemistry, Government Science College - Autonomous, Hassan, Karnataka, India
}

Received 25th May 2020 / Accepted 2nd May 2021

\begin{abstract}
Cerium oxide nanoparticle $\left(\mathrm{CeO}_{2} \mathrm{NPs}\right)$ has wide applications in pharmaceutical, biomedical and chemical industries. Albeit of their uses, bioavailability followed by toxicity of $\mathrm{CeO}_{2} \mathrm{NPs}$ in fresh water fishes, are yet to be understood in detail. In this evaluation, we have synthesized, characterized and assessed the biological effects (hematology, ionoregulatory, oxidative stress, histological and glutamate indices) of $\mathrm{CeO}_{2} \mathrm{NPs}$ at different doses $\left(2.5 \mathrm{mg} / \mathrm{L}\right.$ and $25 \mathrm{mg} / \mathrm{L}$ based on $\left.1 / 10^{\text {th }} \mathrm{LC}_{50}\right)$ on freshwater carps Cirrbinus mrigala, for short term exposure of $96 \mathrm{~h}$. Impact of $\mathrm{CeO}_{2} \mathrm{NPs}$ at low concentration $(2.5 \mathrm{mg} / \mathrm{L})$ confirmed a significant decrease in hematological parameters and also affecting serum $\mathrm{Na}^{+}, \mathrm{Cl}^{-}, \mathrm{K}^{+}$levels along with gill $\mathrm{Na}^{+} / \mathrm{K}^{+}$-ATPase activity. The indicated variations oxidative stress enzymes superoxide dismutase, Catalase, glutathione peroxidase with relative elevation in lipid peroxidation (LPO) $(22.47 \pm 0.198)$ compared to control groups. $\mathrm{CeO}_{2} \mathrm{NPs}$ at high concentration $(25 \mathrm{mg} / \mathrm{L})$ revealed the alterations in neurotransmitter glutamate levels compared to control groups. Rise in glucose and decrease in plasma protein levels in response to both the concentrations was noted. Microscopic observations confirmed the tissue damages and alterations in gill architecture. By integrating all results obtained by short term exposure of juvenile carps to $\mathrm{CeO}_{2} \mathrm{NPs}$ at different doses, we reported nanoparticles have considerable deleterious effects on physiological and morphological condition of fishes.
\end{abstract}

Keywords: cerium oxide nanoparticles, Cirrbinus mrigala, neurotransmitter, oxidative stress

\section{INTRODUCTION}

Over the last decades, nanoparticles have become crucial scientific tool that have found application in diverse fields like nanotechnology, biotechnology, pharmacology and many others which has been owed to their potential to bridge molecular or atomic structures to vast materials (Rashmi et al., 2019). This has led to unforeseen increase in engineered nanoparticles, thus raised concerns over their deleterious effects when interacted with ecosystem at large. Cerium oxide $\left(\mathrm{CeO}_{2}\right) /$ cerium oxide nanoparticles $\left(\mathrm{CeO}_{2} \mathrm{NPs}\right)$ are comprehensively used as additives in diesel fuel (Hendren et al., 2011). However extensive use of $\mathrm{CeO}_{2} \mathrm{NPs}$ result in no point source water pollution, leading to moderate level diverse

*Author for correspondence: Sharath Chandra SP, Department of Biochemistry, Goverment Science College, Hassan, Karnataka, India. Email - biosharath123@gmail.com 
exposure to various flora and fauna (Cassee et al., 1991).

Genotoxic effects of $\mathrm{CeO}_{2} \mathrm{NPs}$ resulting in DNA damage in crustaceans at low dose of $1 \mathrm{mg} / \mathrm{L}$ has been reported (Lee at al., 2009). In-vivo findings in rat and mice have shown inhalation of $\mathrm{CeO}_{2} \mathrm{NPs}$ have induced systematic toxicity in lungs and acute pulmonary toxicity ( $\mathrm{Ma}$ et al., 2012). Investigation on Anabaena, cyanobacteria with an $\mathrm{EC}_{50}$ value of $6.6 \mathrm{mg} / \mathrm{L}$ exhibited cell damage and membrane disruption, rise in reactive oxygen species, lowering in chlorophyll content, and inhibition of photosynthesis (Navarro et al., 2008).

The regular mode of admission of these nanoparticles include organs, olfactory, direct ingestion, entry through gills in fish and by physical defense mechanism like phagocytosis and endocytosis (Sharath et al., 2020). There are documented reports suggesting that small molecules such as nanoparticles associate strongly with living system when compared to bigger molecules (Matranga and Corsi, 2012). These findings have given further reason for investigation of effect of nanoparticles. Consequently, evaluation of ecotoxicity of these $\mathrm{CeO}_{2} \mathrm{NPs}$, are crucial in their further application in nanomedicine and technology (Moore, 2006).

In this direction we adopted Indian fresh water juvenile carp, Cirrbinus mrigala, for the chemical - biological interactions. C. mrigala is widely found in Indian subcontinent and consumed extensively. C. mrigala is considered a sentinel fish, as it is consumed by humans widely and serving as a biomarker for the extent of xenobiotic accumulation in human beings. Studies have shown to use this fish model for similar studies (Perva et al., 2020). Thus understanding the extent of biological variations caused by cerium oxide nanoparticles on C. mrigala will provide the knowledge of their potential appearance in food chain.

The physio biochemical studies such as hematology, ionoregulatory, oxidative stress will provide the changes in physiology happening in fish during exposure to nanoparticles, whereas neurotransmitter (glutamate) analysis will exhibit any impact on brain and gill morphological evaluation will indicate the extent of damage to gill tissue and the degree of interaction (Minghetti and Schirmer, 2016). The gill tissue is the first line of interaction to the nanoparticles, becomes an important morphological indicator of an tissue damage and entry (Shaw and Handy, 2011). Biomarkers are extensively adopted to evaluate the effect of nanoparticles on the physiology, metabolism and biochemistry of aquatic beings (Basuini et al., 2016). Hematological parameters are crucial in determining the possible indication of abnormality and stress in aquatic organisms. Analysis of blood glucose levels and serum protein concentrations indicate the physiological and metabolic condition of the organism. In addition, measurement of ionic concentration like $\mathrm{Na}^{+}, \mathrm{Cl}^{-}, \mathrm{K}^{+}$in blood as well as gill $\mathrm{Na}^{+} / \mathrm{K}^{+}$ATPase also acts as an important indicator of chemical induced toxicity in the organism (Saravanan et al., 2011a). Stress condition leads to the generation of reactive oxygen species in fish with depletion in antioxidants. Measurement of antioxidant enzymes superoxide dismutase, catalase, and glutathione peroxidase and lipid peroxidation demonstrates oxidative damage. Changes in glutamate, a neurotransmitter are investigated, as neurons are vulnerable to oxidative distortion, thus paving way for neurodegenerative problems (Li et al., 2010). As higher concentration of metal oxide NPs in aquatic ecosystem will induce significant alterations in the immune system of fishes and other organisms thus disturbing the ecological balance, determining their degree of toxicity may contribute in alleviating further harm to the ecosystem. Moreover, findings of acute toxicity caused by these NPs are largely unavailable, particularly effect of $\mathrm{CeO}_{2} \mathrm{NPs}$ on fresh water carps are mostly untouched.

In our present study, efforts are made to synthesize and characterize $\mathrm{CeO}_{2} \mathrm{NPs}$ and identify the hematological, physio-biochemical, neurochemical and morphological responses of fresh water juvenile carp, C. mrigala to $\mathrm{CeO}_{2} \mathrm{NPs}$ upon short term exposure of $96 \mathrm{hr}$.

\section{MATERIALS AND METHODS}

\author{
Animals \\ Fresh water juvenile carp, $C$. mrigala $(6.8 \pm 0.8 \mathrm{~cm}$ \\ of body length and $5.8 \pm 1.5 \mathrm{~g}$ of weight) were \\ obtained from fish farm and were stored in
}


dechlorinated water for 15 days. During this phase the fishes were fed with commercial fish food. Debris and residues were cleaned once in a day. The experimental fishes were divided into three groups which were raised in $150 \mathrm{~L}$ aquarium with continuous aeration.

\section{Synthesis and characterization of cerium oxide nanoparticles}

Cerium oxide nanoparticles $\left(\mathrm{CeO}_{2} \mathrm{NPs}\right)$ were synthesized by precipitation method. Cerium nitrate hexahydrate $\left(\mathrm{Ce} \quad\left(\mathrm{NO}_{3}\right)_{3} \cdot 6 \mathrm{H}_{2} \mathrm{O}\right)$ was dissolved in distilled water to prepare 0.1 $\mathrm{mol} / \mathrm{dm}^{3}$ of solution. This aqueous solution was then heated to $26^{\circ} \mathrm{C}$ and consequently precipitated with $0.05 \mathrm{~mol} / \mathrm{dm}^{3}$ of ammonium hydroxide solution. The reaction mixture was then stirred at $25^{\circ} \mathrm{C}$ for $22 \pm 4$ hours. This reaction mixture was centrifuged at $10000 \mathrm{rpm}$, filtered and the resultant product was dried at $150^{\circ} \mathrm{C}$. This sample was further calcined at $600^{\circ} \mathrm{C}$ for 4 hours in a muffle furnace to obtain the desired compound. The compound was further characterized by field emission scanning electron microscope (FE-SEM), Fourier transform infrared spectroscopy (FT-IR), X-ray diffraction studies (XRD) and dynamic light scattering analysis (DLS).

$20 \mathrm{~g} / 1$ of sample solution was readied by adding $\mathrm{CeO}_{2} \mathrm{NPs}$ in double distilled water and was kept for dissolving in a sonicator for 10 hours (Biotechnics). The samples were sonicated further for $1 \mathrm{~h}$ earlier to inoculation each day. Sedimentation of NPs was minimized by providing aeration to the sample, which held them in suspension form. However, a very minor fraction of $\mathrm{CeO}_{2} \mathrm{NPs}$ were found to form aggregates.

\section{Treatment and $L C_{50}$}

The fish groups were treated to $\mathrm{CeO}_{2} \mathrm{NPs}$ for short phase of $96 \mathrm{hr}$. Two varying doses of sample $2.5 \mathrm{mg} / \mathrm{L}$ and $25 \mathrm{mg} / \mathrm{L}$ based on $1 / 10^{\text {th }}$ of $\mathrm{LC}_{50}$ concentration $(250 \mathrm{mg} / \mathrm{L})$ were added into two $120 \mathrm{~L}$ aquariums housing 50 fishes each, along with a control group. Food was withheld $24 \mathrm{hrs}$ before sacrifice to avoid postprandial variations. Initially the mortality was recorded under dose dependent concentrations (500, 375, 250 and 125 $\mathrm{mg} / \mathrm{L}$ ). Since only $90 \%$ mortality was observed below $250 \mathrm{mgl} / \mathrm{L}$, the $\mathrm{LC}_{50}$ of $\mathrm{SnO}_{2} \mathrm{NPs}$ was taken as $250 \mathrm{mgl} / \mathrm{L}$ concentrations at the end of $96 \mathrm{hr}$ observation. Further $1 / 10^{\text {th }}$ and $1 / 100^{\text {th }}$ value was taken for experimentation. Control and exposed fishes $(2.5 \mathrm{mg} / \mathrm{L}$ and $25 \mathrm{mg} / \mathrm{L})$ were used for biological evaluation. Nil mortality was found during the entire 96 hours of exposure to NPs. Water quality was found to be $32.4 \pm 2.4 \mathrm{CaCo}_{3}$ $\mathrm{mg} / \mathrm{L}$ of hardness and a $\mathrm{pH}$ of $7.3 \pm 0.3$, at a constant temperature of $22 \pm 1{ }^{\circ} \mathrm{C}$ with a light dark cycle of 12:12 hrs.

\section{Sample collection and histology}

The fish were euthanized with ice cold water without inducing any stress on fish. The blood samples were drawn from 50 individual fishes (2 replicates) and pool together as three replicates for further analysis. Samples for ionoregulatory studies were transferred into vial without any anticoagulant, as the presence of ions in the same might interfere with results obtained. The samples for hematological and biochemical measurement were introduced to EDTA (Ethylenediaminetetraacetic acid) vials and centrifuged at $9392 \mathrm{~g}$ for $20 \mathrm{~min}$ at $4^{\circ} \mathrm{C}$. The brain samples for neurotransmitter analysis was dissected and placed in ice for analysis. Gills tissue for histopathological evaluation was immediately fixed with 10\% neutral buffered formalin (NBF) overnight. Tissue sections were prepared and stained with hemotoxylin-eosin. The prepared slides were observed and photographs were recorded using Olympus CX41 microscope mounted with camera.

\section{Hematological measurements}

Red blood cells, white blood cells were counted using neubauer hemocytometer. Cyanomethemoglobin method was employed to measure the amount of hemoglobin $(\mathrm{Hb})$ content in blood. Hct percentage was estimated by using the microhematocrit methodology (Nelson and Morris.1989). Mean corpuscular volume (MCV), Mean corpuscular haemoglobin $(\mathrm{MCH})$ and Mean corpuscular haemoglobin concentration (MCHC) were determined using established formulas for three replicates.

\section{Biochemical measurements}

Biochemical measurements were carried out for three replicates. Blood glucose was determined by Cooper and McDaniel 1970 method. The glucose 
levels were measured as $\mathrm{mg} / \mathrm{dL}$. Plasma protein levels were determined by Lowry's method. The sample was read at $720 \mathrm{~nm}$ and measured in $\mu \mathrm{g} / \mathrm{ml}$.

\section{Ionoregulatory studies}

Plasma sodium was estimated by adding $1000 \mu \mathrm{l}$ of precipitating reagent with $20 \mu \mathrm{l}$ of sample. 20 $\mu \mathrm{l}$ of standard was mixed instead of sample for tube assigned as standard. The readings were taken at $550 \mathrm{~nm}$ and expressed as $\mathrm{mEq} / \mathrm{L}$. Similarly, potassium was estimated at $630 \mathrm{~nm}$. Plasma chloride was read against blank at $505 \mathrm{~nm}$ and the concentration was measured in $\mathrm{mEq} / \mathrm{L}$. Gills $\mathrm{Na}^{+} / \mathrm{K}^{+}$-ATPase activity was performed and expressed as $\mu \mathrm{g} / \mathrm{h} / \mathrm{g}$ (Evans et al., 2005). Experiments were performed for three replicates.

\section{Oxidative stress and neurotransmitter assessment}

Superoxide dismutase was determined (Das et al., 2000) by blocking superoxide led nitrite formation from hydroxylamine hydrochloride and activity was measured as $\mathrm{U} / \mathrm{mg}$ of protein. Catalase activity was read at $405 \mathrm{~nm}$ and expressed as $\mathrm{U} / \mathrm{mg}$ (Goth, 1991). Glutathione peroxidase (GPx) was measured by Rotruck et al. (1973).The samples in triplicates were measured at $412 \mathrm{~nm}$ and the enzyme was reported as $\mathrm{mU} / \mathrm{mg}$ of protein. Lipid peroxidation was demonstrated by using malondialdehyde (MDA) as a standard (Buege and Aust, 1978) and expressed in terms of thiobarbituric acid (TBARS). Glutamate was analyzed by development of paper chromatography (Raju et al., 2004). Experiments were performed for three replicates.

\section{Statistical analysis}

All the data was statistically evaluated and put forth as Mean \pm SE. In all assays, the amount of statistical significance was fixed for $\mathrm{P}<0.05$. The significance was calculated by one way ANOVA analysis with post-hoc corrected $\mathrm{t}$ tests.

\section{RESULTS AND DISCUSSION}

\section{Characterization of cerium oxide nanoparticles}

The structural characterization of the synthesized cerium oxide nanoparticles was analyzed using
Powder X-Ray Diffraction (PANalytical X'Pert) system. The XRD pattern of cerium oxide nanoparticles can be found in Figure 1(A). The XRD pattern established the polycrystalline property of cerium oxide nanoparticles. The XRD pattern was obtained by scanning the sample at $2 \theta$ from 10-80 degrees. Maximum intensity peaks were seen 28.65, 33.45, 48.7, 58.4, and XRD indices were 111, 220, 200, 311 crystal planes respectively. The diffraction peaks obtained in the XRD pattern reflects the pure structure of cubic cerium fluorite while comparing to the standard. The crystal planes calculated were in agreement with JCPDS No: 34-0394. The unit cell properties of the cerium oxide nanoparticles were determined using the UNITCELL software. The crystal size was found using full Width at Half Maximum (FWHM) of the respective peaks. The images of $\mathrm{CeO}_{2} \mathrm{NPs}$ captured in Field emission scanning electron microscope (FESEM) are shown in Figure 1(B). The grains observed are similar and spherical in shape when observed from FESEM with minor aggregation and size variation from 10 and $75 \mathrm{~nm}$. The recorded values are similar to the investigation conducted by other research groups (Meron and Markovich, 2005). The small aggregation of spherical $\mathrm{CeO}_{2} \mathrm{NPs}$ can be associated to consistent arrangement of the primary particles. The FT-IR spectrum of cerium oxide nanoparticles annealed at $600^{\circ} \mathrm{C}$ can be seen Figure $1(\mathrm{C})$. The broad spectrum band found at $3430 \mathrm{~cm}^{-1}$ is attributed to the $\mathrm{OH}$ vibrational stretching of hydroxyl groups and residual water, while the scissor bending property of the associated water molecule can be found at absorption band reading $1633 \mathrm{~cm}^{-1}$. The surfactant free property of the synthesized $\mathrm{CeO}_{2} \mathrm{NPs}$ can be confirmed by the occurrence of absorption band at $2929 \mathrm{~cm}^{-1}$. The absorption band at $3430 \mathrm{~cm}^{-1}$ and $1633 \mathrm{~cm}^{-1}$ can be ascribed to the $\mathrm{OH}$ of the absorbed water on the surface of the sample. Further band recorded at $487 \mathrm{~cm}^{-1}$ is attributed to the stretching frequency of $\mathrm{Ce}-\mathrm{O}$ bonds, while absorption band at $1113 \mathrm{~cm}^{-1}$ is corresponding to the metal oxygen (Ce-O) vibrations. The aqueous suspension of $\mathrm{CeO}_{2} \mathrm{NPs}$ was filtered using $0.22 \mu \mathrm{m}$ syringe associated filter and the size of the $\mathrm{CeO}_{2} \mathrm{NPs}$ was reported by dynamic light scattering (DLS) using Malvern zetasizer nano series spectrometer. Figure 1(D) shows the size distribution for $\mathrm{CeO}_{2} \mathrm{NPs}$ obtained 
from individual run. The mean hydrodynamic size of the particles was found to be $344.2 \mathrm{~d} . \mathrm{nm}$. The hydrodynamic data obtained can be found to be independent of the primary particle size, indicating that the $\mathrm{CeO}_{2} \mathrm{NPs}$ are agglomerated when dispersed in the double distilled water.

\section{Effect of cerium oxide nanoparticles on hematological parameters}

Table.1 demonstrates the hematological variables. The distinct and moderate variations in different blood indices were observed between control and the treated fishes. In this investigation significant $(P<0.05)$ decline of MCV, MCH, MCHC, Hct, in treated fishes were observed compared to the control fishes. Major difference in MCV and MCHC values was found in treated groups compared to the untreated fishes exposed to cerium oxide nanoparticles, while there was a definite increase in the WBC levels in control and treated groups. Further notable changes were observed in the RBC, Hb levels. Accumulation of toxic pesticides in the body has been reported to cause deteriorating and damaging effects in the hematological and hematic systems (Seth and Saxena, 2003). The reduced MCV and RBC count reported in the present study are major indicators of anemia. The development of anemia may be ascribed to the interference of the NPs with growth and development of hematopoietic progenitor and variations in the generation of renal erythropoietin. The $\mathrm{MCH}, \mathrm{MCV}$ and $\mathrm{MCHC}$ values indicate the damage and destruction of blood cells upon treatment with NPs. Alterations in the leucocytes indices in the stress induced animals are characterized by lymphopenia and heterophilia due to leucocytosis (Saravanan et al., 2011b), whereas increased values of WBC may be because of short term spur in the specific immune responses.
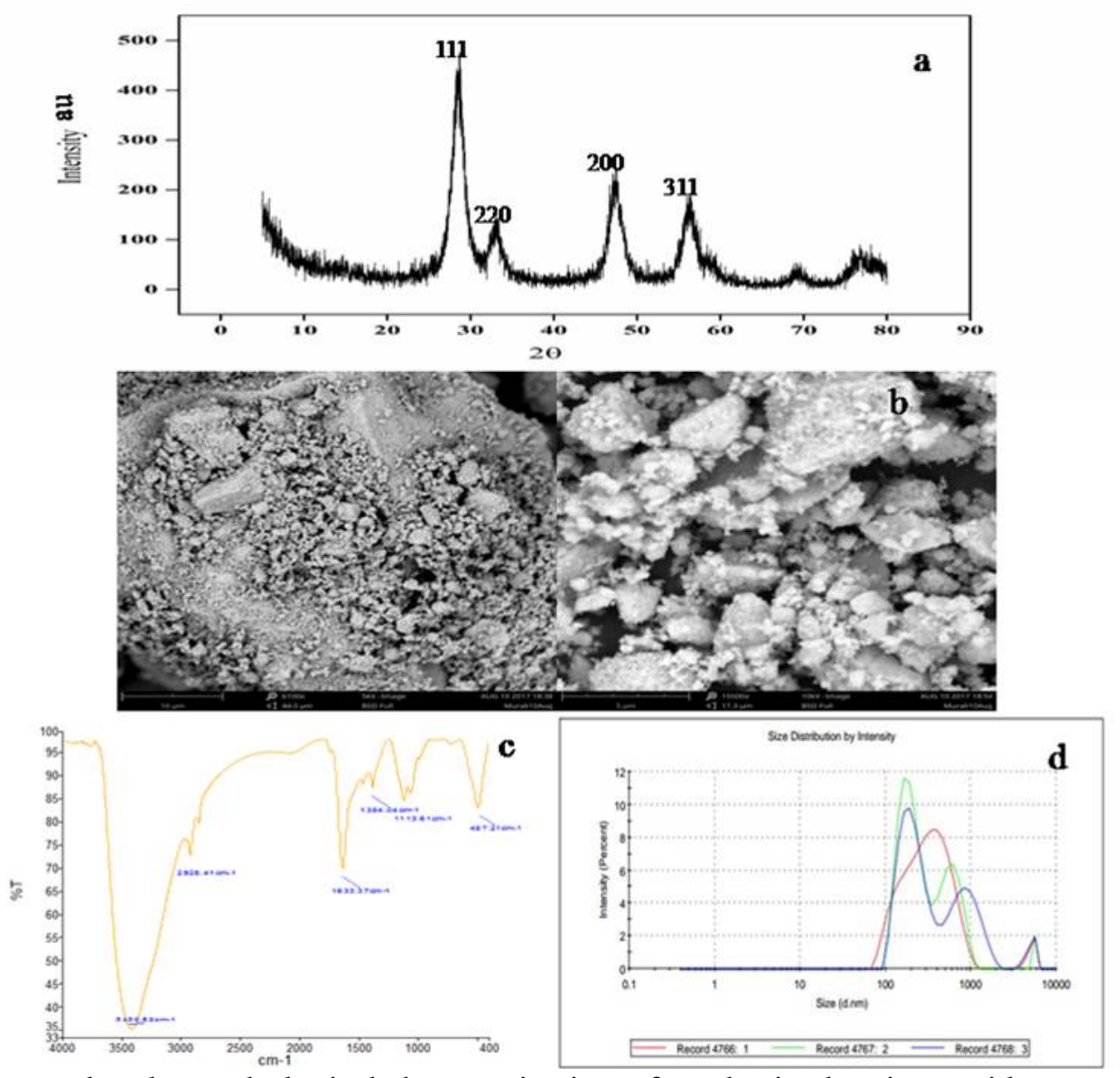

Figure 1. Structural and morphological characterization of synthesized cerium oxide nanoparticles. (A) X ray diffraction pattern (B) scanning electron microscope images (C) FTIR profile (D) Dynamic light scattering analysis. 
Table 1. Alterations in the haematological indices of $C$ mrigala exposed to different doses $(2.5$ and 25 $\mathrm{mg} / \mathrm{L}$ for $96 \mathrm{~h}$ ) of cerium oxide nanoparticles with $\mathrm{n}=3$.

\begin{tabular}{cccc}
\hline Haematological & \multicolumn{3}{c}{$\mathbf{9 6} \mathbf{h}$} \\
\cline { 2 - 4 } Indices & Control & $\mathbf{2 . 5} \mathbf{~ m g} / \mathbf{L}$ & $\mathbf{2 5} \mathbf{~ m g} / \mathbf{L}$ \\
\hline $\mathrm{RBC}(\mathrm{millions} / \mathrm{Cumm})$ & $0.76 \pm 0.014$ & $0.53 \pm 0.005^{*}$ & $0.68 \pm 0.04^{*}$ \\
$\mathrm{WBC}\left(10^{3} / \mathrm{mm}^{3}\right)$ & $17.38 \pm 0.15$ & $34.48 \pm 1.24$ & $35.58 \pm 0.23^{*}$ \\
$\mathrm{Hb}(\mathrm{g} / \mathrm{dL})$ & $4.87 \pm 0.16$ & $2.56 \pm 0.05^{*}$ & $4.02 \pm 0.12$ \\
$\mathrm{Hct}(\%)$ & $14.23 \pm 0.02$ & $7.42 \pm 0.12^{*}$ & $10.57 \pm 0.20^{*}$ \\
$\mathrm{MCV}\left(\mu \mathrm{m}^{3}\right)$ & $185.06 \pm 0.32$ & $63.5 \pm 0.17^{*}$ & $34.73 \pm 0.26^{*}$ \\
$\mathrm{MCH}(\mathrm{pg})$ & $137.05 \pm 0.47$ & $47.51 \pm 0.28^{*}$ & $53.66 \pm 0.34$ \\
$\mathrm{MCHC}(\mathrm{g} / \mathrm{dL})$ & $153.53 \pm 0.23$ & $58.5 \pm 0.28^{*}$ & $37.99 \pm 0.26^{*}$ \\
\hline
\end{tabular}

Hb: Haemoglobin, MCV: Mean corpuscular volume, MCH: Mean corpuscular haemoglobin,MCHC: Mean corpuscular heamoglobin concentration. All values are expressed as mean $\pm \mathrm{SE}, * P<0.05$ is significant.

\section{Effect of cerium oxide nanoparticles on physio- biochemical variables}

Table 2 show the effect of $\mathrm{CeO}_{2} \mathrm{NPs}$ on blood glucose concentration compared to the control groups. There was a significant $(P<0.05)$ increase in both the treated groups $(2.5 \mathrm{mg} / \mathrm{L}$ and 25 $\mathrm{mg} / \mathrm{L})$ when compared to the control fishes. Variations in the plasma glucose levels are attributed to the stress induced hypoxia and gluconeogenesis in fishes (Lavanya et al., 2011). Whereas stress induced increase in glucose concentration in animals were also associated to the enhanced production of glucose which in turn is metabolized to energy molecules (ATP) to replenish additional energy requirement, while respiratory insufficiency may also be a crucial factor leading to increased level of blood glucose. The lowering in plasma protein concentration was significantly $(P<0.05)$ recorded in both the groups $(2.5 \mathrm{mg} / \mathrm{L}$ and $25 \mathrm{mg} / \mathrm{L})$ exposed to cerium oxide nanoparticles. Liver and gill tissue injury, oxidative stress, changes in hematological properties followed by protein structure conformational alterations due to NPs binding to blood and tissue proteins has been reported (Chen et al., 2011). This observation suggests the reason for decrease of protein concentration in present study. Toxicity of NPs can be the reason for lowered protein concentration as it impedes translational and transcription mechanisms.

\section{Effect of cerium oxide nanoparticles on ionoregulatory function of gills}

Table 2 shows that there was significant $(P<0.05)$ decrease in gill $\mathrm{Na}^{+} / \mathrm{K}^{+}$ATPase activity in the groups exposed to both concentration $(2.5 \mathrm{mg} / \mathrm{L}$ and $25 \mathrm{mg} / \mathrm{L}$ ) compared to control groups. This might be attributed to the fact that toxic substances were known to inhibit the activity followed by ionic imbalances (Wood et al., 1996). Toxic substances were absorbed by gill cells through proton coupled $\mathrm{Na}^{+}$channels and this reportedly blocked the $\mathrm{Na}^{+} \mathrm{K}^{+}$ATPase (Bury and Wood, 1999). The binding of toxic molecules to the amino acid containing sulfhydryl functional groups of $\mathrm{Na}^{+} / \mathrm{K}^{+}$ATPase has been demonstrated as the important factor for the inhibition of $\mathrm{Na}^{+} / \mathrm{K}^{+}$ATPase activity and was reconfirmed by downregulation of $\mathrm{Na}^{+} / \mathrm{K}^{+}$ATPase genes in the gills of zebrafish (Foyer and Noctor, 2005). Thus the present findings can be considered as the direct interaction of gills to cerium oxide nanoparticles and their uptake by $\mathrm{Na}^{+}$channels. The findings also revealed that the decreased concentration of plasma $\mathrm{Na}^{+}, \mathrm{K}^{+}$and $\mathrm{Cl}^{-}$in the treated groups, with fishes exposed to $25 \mathrm{mg} / \mathrm{L}$ exhibiting prominent decline in ionic levels, in contrast to the control groups. This condition might be associated to the reduced intake of electrolytes or decreased efflux of the same ions from intracellular matrix to extracellular fluid. The gills of fish act as the main bridge between the surrounding aqueous environment and the blood, which is the main physiological regulator (Chandra et al., 2017). This along with its other vital properties like gaseous exchange and osmoregulation makes gill tissue a suitable model to investigate the effect of toxic molecules. 
Table 2. Alterations in the physio-biochemical parameters of $\mathrm{C}$ mrigala exposed to different doses (2.5 and $25 \mathrm{mg} / \mathrm{L}$ for $96 \mathrm{~h}$ ) of cerium oxide nanoparticles with $\mathrm{n}=3$.

\begin{tabular}{cccc}
\hline Biochemical parameters/ & \multicolumn{3}{c}{$\mathbf{9 6} \mathbf{~ h}$} \\
\cline { 2 - 4 } $\begin{array}{c}\text { Ionoregulatory } \\
\text { indices }\end{array}$ & Control & $\mathbf{2 . 5} \mathbf{~ m g} / \mathbf{L}$ & $\mathbf{2 5} \mathbf{~ m g} / \mathbf{L}$ \\
\hline Blood glucose $(\mathrm{mg} / \mathrm{dL})$ & $143.66 \pm 3.4$ & $172 \pm 4.64^{*}$ & $180.33 \pm 2.02^{*}$ \\
Plasma protein $(\mu \mathrm{g} / \mathrm{mL})$ & $14.29 \pm 0.24$ & $2.8 \pm 0.20^{*}$ & $5.87 \pm 0.19^{*}$ \\
Sodium $(\mathrm{mEq} / \mathrm{L})$ & $224.83 \pm 0.44$ & $155.33 \pm 3.52^{*}$ & $110.5 \pm 1.44$ \\
Potassium $(\mathrm{mEq} / \mathrm{L})$ & $4.526 \pm 0.15$ & $3.7 \pm 2.017^{*}$ & $2.37 \pm 0.15^{*}$ \\
Chloride $(\mathrm{mEq} / \mathrm{L})$ & $154.33 \pm 2.33$ & $105.66 \pm 2.96$ & $72.16 \pm 3.14^{*}$ \\
Gills Na+K+ATPase $(\mu \mathrm{g} / \mathrm{h} / \mathrm{g})$ & $22.53 \pm 0.14$ & $12.56 \pm 0.18^{*}$ & $8.43 \pm 0.12^{*}$ \\
\hline
\end{tabular}

All values are expressed as mean $\pm \mathrm{SE}, * P<0.05$ is significant.

\section{Superoxidedismutase}

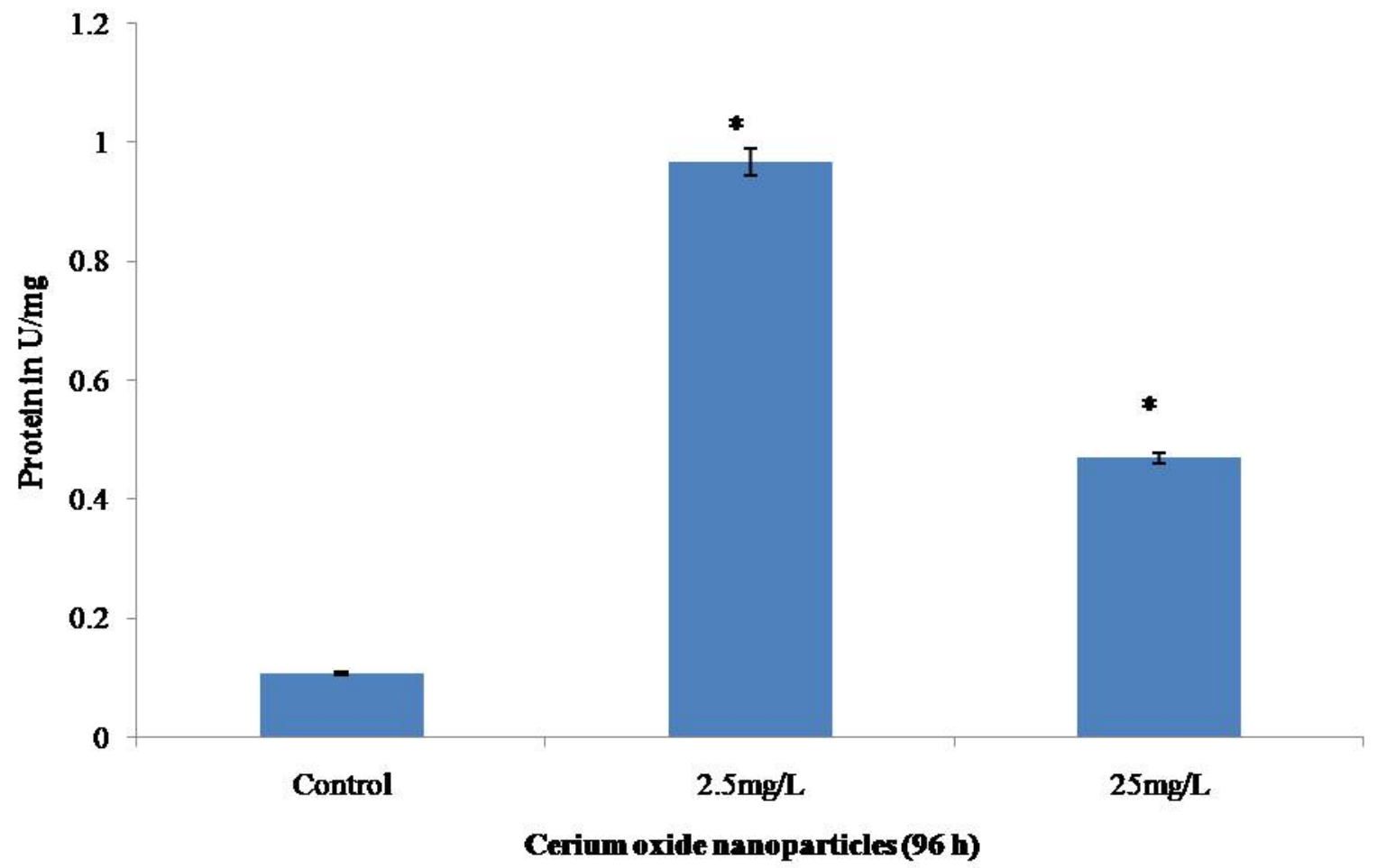

Figure 2. Changes in blood SOD levels in $C$ mrigala exposed to different doses of $\mathrm{CeO}_{2} \mathrm{NPs}(2.5 \mathrm{mg} / \mathrm{L}$ and $25 \mathrm{mg} / \mathrm{L}, 96 \mathrm{~h})$. Expressed as mean $\pm \mathrm{SE}(* \mathrm{P}<0.05-\mathrm{t}$ test) with $\mathrm{n}=3$.

\section{Effect of cerium oxide nanoparticles on blood plasma antioxidant enzyme system}

Figure 2 shows that the increase in superoxide dismutase (SOD) levels in fishes treated to both the concentrations $(2.5 \mathrm{mg} / \mathrm{L}$ and $25 \mathrm{mg} / \mathrm{L})$, this might be due to the production of SOD to compete and scavenge the excessive generation of reactive oxygen species (Puneeth and Chandra, 2020) due to cellular injury and damage from $\mathrm{CeO}_{2} \mathrm{NPs}$. Figure 3 shows the significant lowering in catalase activity in fishes treated to both the concentrations; this reveals the interference of $\mathrm{CeO}_{2} \mathrm{NPs}$ to induce peroxidative damage. Catalase has been reported to translate numerous hydrogen peroxide to water and oxygen per second (El-Gendy et al., 2009). Impair in catalase activity will enhance the ROS production and leading to more deterioration of tissues. Figure 4 reports the decrease in the antioxidant enzyme glutathione peroxidase (GPx) activity significantly 
$(P<0.05)$, when treated to both concentrations of cerium oxide nanoparticles, which are indication of augmented oxidative stress due to the interaction of NPs. GPx protects the cellular membranes by eliminating lipid peroxide and hydrogen peroxide, thus alleviating damage caused due to peroxidation. But the inhibition of GPx can be directly associated with toxicity of NPs to the fishes. Figure 5 shows that the dose dependent increase in the malondialdehyde concentration was observed. This results for increased lipid peroxidation in the treated groups, thus leading to changes in the cellular membranes. Malondialdehyde is an important biomarker of oxidative stress and damage. Increased lipid peroxidation and oxidative damage has been reported extensively in liver and other tissues in fish (Perva et al., 2020).

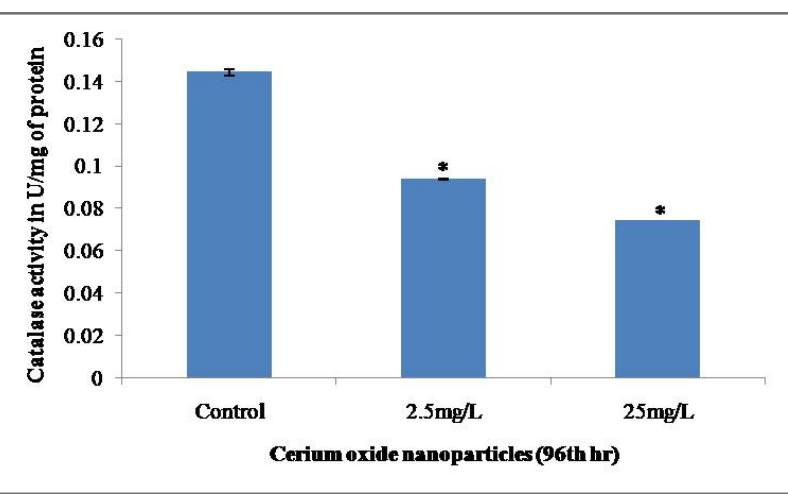

Figure 3. Changes in plasma CAT levels in $C$ mrigala exposed to different doses of $\mathrm{CeO}_{2} \mathrm{NPs}$ $(2.5 \mathrm{mg} / \mathrm{L}$ and $25 \mathrm{mg} / \mathrm{L}, 96 \mathrm{~h})$. Expressed as mean $\pm \mathrm{SE}(* \mathrm{P}<0.05$ - $\mathrm{t}$ test $)$ with $\mathrm{n}=3$.

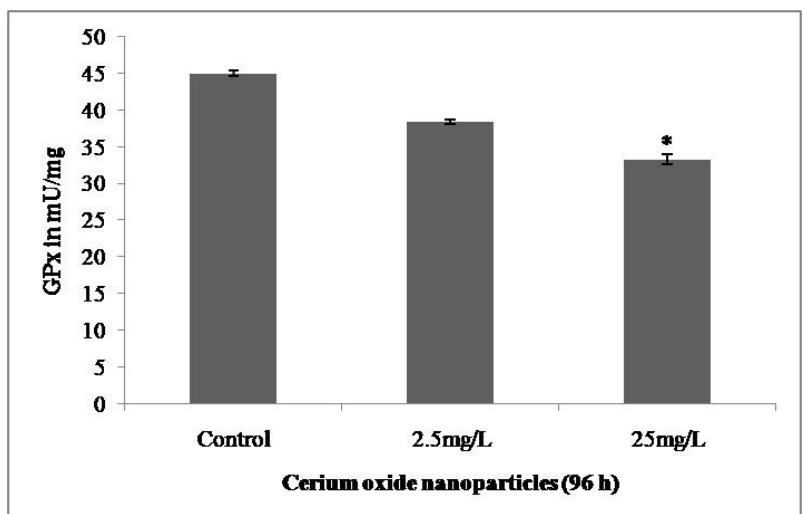

Figure 4. Alterations in GPx levels in $C$ mrigala exposed to different doses of $\mathrm{CeO}_{2} \mathrm{NPs}$ (2.5 $\mathrm{mg} / \mathrm{L}$ and $25 \mathrm{mg} / \mathrm{L}, 96 \mathrm{~h}$ ). Expressed as mean \pm $\mathrm{SE}(* \mathrm{P}<0.05-\mathrm{t}$ test $)$ with $\mathrm{n}=3$.

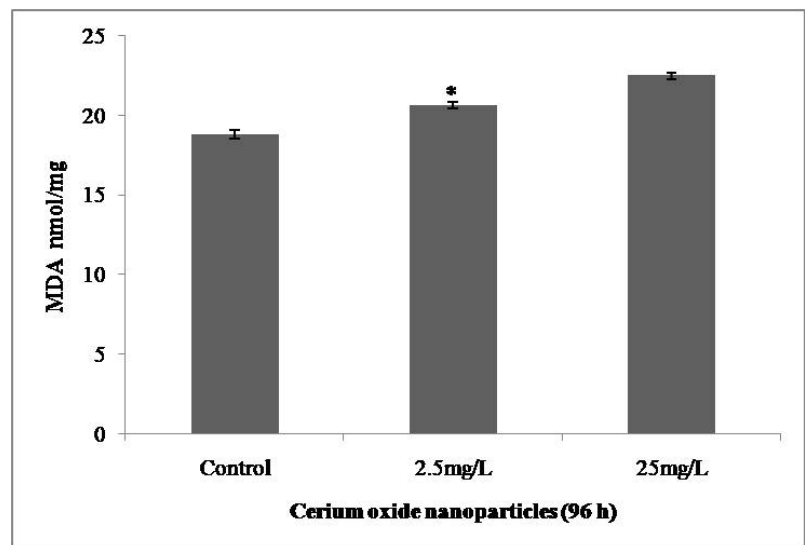

Figure 5. Changes in MDA concentration in $C$ mrigala, which were exposed to different levels of $\mathrm{CeO}_{2} \mathrm{NPs}(2.5 \mathrm{mg} / \mathrm{L}$ and $25 \mathrm{mg} / \mathrm{L}, 96 \mathrm{~h})$. Expressed as mean $\pm \mathrm{SE}(* \mathrm{P}<0.05-\mathrm{t}$ test $)$ with $\mathrm{n}=3$.

Effect of cerium oxide nanoparticles on glutamate levels in brain tissue

Figure 6 shows that the dose dependent variation was also found in levels of glutamate concentration, a neurotransmitter in the brain tissue. This could be associated with exo-toxicity, due to increased generation of glutamate, which might lead to depletion of nerve cells (Chandra et al., 2020). The increased glutamate levels contribute to changes in brain environment which activates the glutamate receptors by permitting excess levels of calcium ions to permeate the cell (Duman et al., 2019; Manev et al., 1999).

\section{Effect of cerium oxide nanoparticles by histopathological studies}

Figure 7 shows gill tissue histopathological studies, which revealed several histological variations such as lifting of epithelial layer, cellular degeneration, aneurysm, hemorrhage and loss of structure. The examination exhibited cellular degeneration at both the concentrations (2.5 $\mathrm{mg} / \mathrm{L}$ and $25 \mathrm{mg} / \mathrm{L}$ ) whereas loss of structure, hemorrhage and absence of respiratory epithelium was observed in animals treated with higher concentration $(25 \mathrm{mg} / \mathrm{L})$. The gills are directly exposed to toxic molecules in the outer environment, which leads to pathological conditions (Mallat, 1985), thus making it a vulnerable structure. It has been reported that high concentration of ultra-small molecules is phagocytosed by the epithelial cells and this uptake makes way for the entry of such NPs resulting absorption and binding to cell walls and 
cell membranes. Figure 7 (A) and $7(B)$ show normal structure of gill morphology in control fish, including intact primary and secondary lamellae. Figure $7(\mathrm{C})$ at lower dose $2.5 \mathrm{mg} / \mathrm{L}$ shows hemorrhage (arrow) due to gill hyperplasia which results in increased epithelial thickness and thus decline into blood stream. Aneurysm (dotted arrow) in Figure 7 (C) has been attributed to toxin induced alterations in the pillar cell structure, and thus loss of their function. Figure 7 (D), with higher concentration of $25 \mathrm{mg} / \mathrm{L}$ demonstrated, absence of respiratory epithelium and loss of structure due to interaction of NPs with gill epithelium (Figueiredo et al., 2007). Figure 7 (F) shows lamellar fusion at higher concentration of $25 \mathrm{mg} / \mathrm{L}$, owing to the thickening of gill filament epithelium from cell proliferation. The fusion of gill lamellae has been attributed to the toxin which changes the glycoprotein in the mucus covering of the cells, which further disturbs the negative charges of the epithelium and thus leads to fusion to the adjacent lamellae. Figure 7 (E) confirms lifting of lamellar epithelium (dotted arrow) indicating the defense mechanism. The separation of epithelial increases the space which withheld diffusion of toxins from the water into the blood stream and further resulting in hemorrhage (arrow) at high doses $25 \mathrm{mg} / \mathrm{L}$. Most of the above histological variations are result of defense mechanism against the toxic molecules thus establishing the responses of carps against cerium oxide nanoparticles.

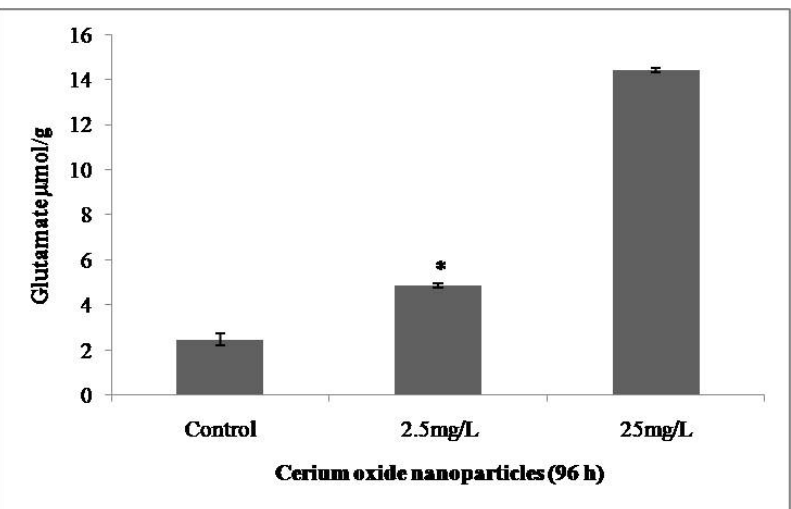

Figure 6. Variations in brain glutamate concentration in $C$ mrigala exposed to different doses of $\mathrm{CeO}_{2} \mathrm{NPs}(2.5 \mathrm{mg} / \mathrm{L}$ and $25 \mathrm{mg} / \mathrm{L}, 96$ h). Expressed as mean $\pm \mathrm{SE}(* \mathrm{P}<0.05-\mathrm{t}$ test $)$ with $\mathrm{n}=3$.

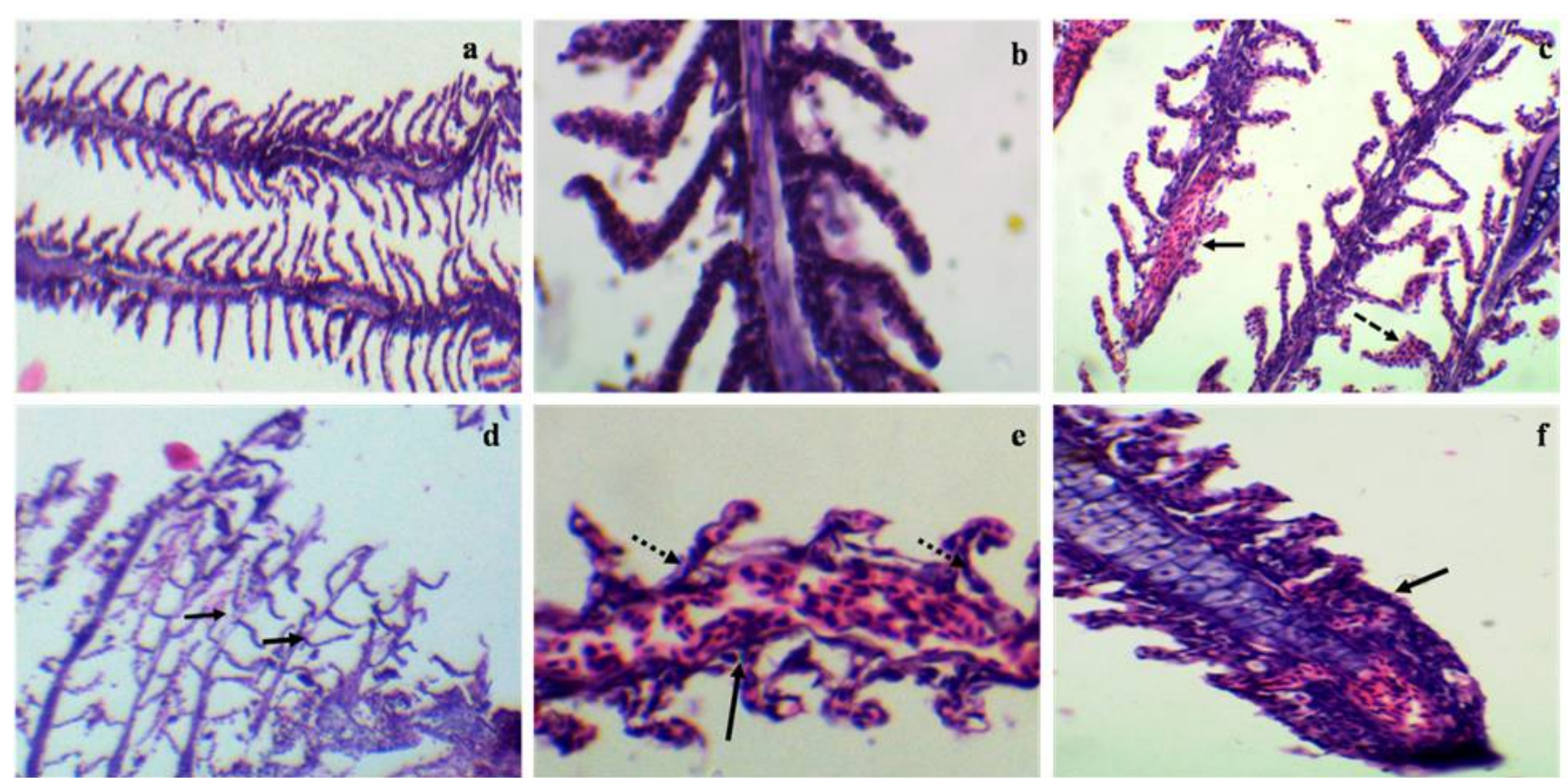

Figure 7. Histopathological analysis of C.mrigala Gills after 96 h. (A) 20x section from control fishes shows normal gill architecture (B) 40X section of primary and secondary lamellae from control fishes shows normal gill architecture (C) 20x section from treated fishes with $2.5 \mathrm{mg} / \mathrm{L}$ of $\mathrm{CeO}_{2} \mathrm{NPs}_{\mathrm{s}}$ shows aneursym (dotted arrow) and hemorrhage (arrow) (D) 20x section from treated fishes $(25 \mathrm{mg} / \mathrm{L})$ shows absence of respiratory epithelium and loss of structure (E) 40x section from treated fishes $(25 \mathrm{mg} / \mathrm{L})$ shows hemorrhage (arrow) and moderate lifting of epithelial and cellular degeneration (dotted arrow) (F) $40 \mathrm{X}$ section of treated fish $(25 \mathrm{mg} / \mathrm{L})$ show complete fusion of several lamellae. 


\section{CONCLUSION}

The novelty in the work is the fact that no earlier reports have been found with regard to interaction of cerium oxide nanoparticles with fresh water fishes. The changes in haematological parameters, namely $\mathrm{WBC}$ and $\mathrm{MCHC}$ levels provide more insight into the toxic effects of $\mathrm{CeO}_{2} \mathrm{NPs}$. Biochemical markers also indicate oxidative damage through lipid peroxidation, SOD, catalase, GPx. Significant increase in the neurotransmitter, glutamate levels particularly at higher doses shows minor neurotoxicity impact of $\mathrm{CeO}_{2} \mathrm{NPs}$. Histopathological studies of fish gills, shows the direct evidence of toxicity of $\mathrm{CeO}_{2} \mathrm{NPs}$. Thus controlled discharge and neutralization $\mathrm{CeO}_{2} \mathrm{NPs}$ before discharge to the environment is essential. However chronic exposure of fresh water fishes to $\mathrm{CeO}_{2} \mathrm{NPs}$ have to be evaluated, and further proteomic and genomics studies might reveal effects of $\mathrm{CeO}_{2} \mathrm{NPs}$ at molecular level.

\section{REFERENCES}

Buege, J. A. \& Aust, S. D. Microsomal lipid peroxidation. 1978. Methods in Ensymology 52: 302-10.

Bury, N. R. \& Wood, C. M. 1999. Mechanism of branchial apical silver uptake by rainbow trout is via the proton-coupled $\mathrm{Na}+$ channel. American Journal of Physiology - Regulatory, Integrative and Comparative Physiology 277: 1385-91.

Cassee, F. R., van Balen, E. C., Singh, C., Green, D., Muijser, H., Weinstein, J., \& Dreher K. 1991. Exposure, health and ecological effects review of engineered nanoscale cerium and cerium oxide associated with its use as a fuel additive. Critical Reviews in Toxicology 41: 213-29.

Chandra, S. P., Puneeth, H. R., Mahadimane, P. V., \& Sharada, A. C. 2017. Biochemical evaluation of Cordiadichotoma seed extracts. Advanced Science Letters 23(3): 1823-1825.

Chandra, S. \& Sukumaran., S. 2020. Physiological, Biochemical and Neurochemical responses of Cirrbinus mrigala upon short term exposure to Cerium oxide. International Journal of Aquatic Biology 7(6): 368-373.

Chen, P. J., Su, C. H., Tseng, C. Y., Tan, S. W., \& Cheng, C. H. 2011. Toxicity assessments of nanoscale zerovalent iron and its oxidation products in medaka (Oryzias latipes) fish. Marine Pollution Bulletin 31: 339-46.

Cooper, G. R. \& McDaniel, V. 1970. Standard methods of clinical chemistry. Academic, New York. 159.

Das, K., Samanta, L., \& Chainy, G. B. N. 2000. A modified spectrophotometric assay of superoxide dismutase using nitrite formation by superoxide radicals. Indian Journal of Biochemistry and Biophysics 37: 201-204.

Duman, R. S., Sanacora, G., \& Krystal, J. H. 2019. Altered connectivity in depression: GABA and glutamate neurotransmitter deficits and reversal by novel treatments. Neuron 102(1): 75-90.

El Basuini, M. F., El-Hais, A. M., Dawood, M. A., Abou-Zeid, A. E. S., EL-Damrawy, S. Z., Khalafalla, M. M. E. S., Koshio, S., Ishikawa, M. \& Dossou, S. 2016. Effect of different levels of dietary copper nanoparticles and copper sulfate on growth performance, blood biochemical profiles, antioxidant status and immune response of red sea bream (Pagrus major). Aquaculture 455: 32-40.

El-Gendy, K. S., Radwan, M. A., \& Gad, A. F. 2009. In vivo evaluation of oxidative stress biomarkers in the land snail, Theba pisana exposed to copper-based pesticides. Chemosphere 31: 339-44.

Evans, D. H., Piermarini, P. M., \& Choe, K. P. 2005. The multifunctional fish gill: dominant site of gas exchange, osmoregulation, acid-base regulation, and excretion of nitrogenous waste. Physiological Reviews 85: 97-177.

Figueiredo-Fernandes, A., Ferreira-Cardoso, J. V., Garcia-Santos, S., Monteiro, S. M., Carrola, J., Matos, P., \& FontaínhasFernandes, A. 2007. Histopathological changes in liver and gill epithelium of Nile tilapia, Oreochromis niloticus, exposed to waterborne copper. Pesquisa Veterinária Brasileira 27: 103 109.

Foyer, C. H. \& Noctor, G. 2005. Oxidant and antioxidant signalling in plants: a re-evaluation of the concept of oxidative stress in a physiological context. Plant Cell Environment 28: 1056-71.

Goth, L. A. 1991. Simple method for determination of serum catalase activity and revision of reference range. Clinca Chimca Acta 15: 143-51.

Hendren, C. O., Mesnard, X., Droege, J., Wiesner, M. R. 2011. Estimating production data for five engineered nanomaterials as a basis for exposure assessment. Environmental Science and Technology 45: 2562-2569.

Lavanya, S., Ramesh, M., Kavitha, C., \& Malarvizhi A. 2011. Hematological, biochemical and ionoregulatory responses of Indian major carp Catla catla during chronic sublethal exposure to inorganic arsenic. Chemosphere 28: 977-85.

Lee, S. W., Kim, S. M., \& Choi, J. 2009. Genotoxicity and ecotoxicity assays using the freshwater crustacean Daphnia magna and the larva of the aquatic midge Chironomus riparius to screen the ecological risks of nanoparticle exposure. Environmental Toxicology and Pharmacology 31: 86-91.

Li, Z. H., Zlabek, V., Velisek, J., Grabic, R., Machova, J., \& Randak, T. 2010. Modulation of antioxidant defence system in brain of rainbow trout (Oncorbyncbus mykiss) after chronic carbamazepinetreatment.Comparative Biochemistry and Physiology Part C: Toxicology \& Pharmacology 31: 137-41.

Ma, J. Y., Mercer, R. R., Barger, M., Schwegler-Berry, D., Scabilloni, J., Ma, J. K., \& Castranova, V. 2012. Induction of pulmonary fibrosis by cerium oxide nanoparticles. Toxicology and Applied Pharmacology 262: 255-64.

Mallatt, J. Fish gill structural changes induced by toxicants and other irritants: a statistical review. The Canadian Journal of Fisheries and Aquatic Sciences 1985: 42:630-48.

Manev, H., Favaron, M. A., Guidotti, A. L, \& Costa, E. R. 1989. Delayed increase of $\mathrm{Ca}^{2+}$ influx elicited by glutamate: role in neuronal death. Molecular Pharmacology 36: 106-12.

Matranga, V. \& Corsi, I. 2012. Toxic effects of engineered nanoparticles in the marine environment: model organisms and molecular approaches. Marine Environmental Research 31: $32-40$

Meron, T. \& Markovich, G. 2005. Ferromagnetism in colloidal $\mathrm{Mn}^{2+}$-doped $\mathrm{ZnO}$ nanocrystals. The Journal of Physical Chemistry B 109: 20232-6.

Minghetti, M. \& Schirmer, K. 2016. Effect of media composition on bioavailability and toxicity of silver and silver 
nanoparticles in fish intestinal cells (RTgutGC). Nanotoxicology 10(10): 1526-34.

Moore, M. N. 2006. Do nanoparticles present ecotoxicological risks for the health of the aquatic environment?. Environment International 31: 967-76.

Navarro, E., Baun, A., Behra, R., Hartmann, N. B., Filser, J., Miao, A. J., Quigg, A., Santschi, P. H., \& Sigg, L. 2008. Environmental behavior and ecotoxicity of engineered nanoparticles to algae, plants, and fungi. Ecotoxicology 17: 372-86.

Nelson, D. A. \& Morris, M. W. 1989. Basic methodology. Hematology and coagulation, part IV. Clinical diagnosis and management by laboratory methods 7 th edn. Saunder Company, Philadelphia. 578-724.

Perva, S., Swamy, K., Chandrashekar, N., Subramanian, R., Sukumaran, S., \& Chandra SP, S. 2020. Physio-biochemical responses of Indian major carp Catla catla upon sub-chronic exposure to tin oxide nanoparticles. Egyptian Journal of Aquatic Biology and Fisheries 24(4): 509-520.

Puneeth, H. R. \& Chandra, S. S. P. 2020. A review on potential therapeutic properties of Pomegranate (Punica granatum L.). Plant Science Today 7(1): 9-16.

Raju, T. R., Kutty, B. M., Sathyaprabha, T. N., \& Shankarnarayana, R. 2004. BS. Brain and behavior. National Institute of Mental Health and neurosciences, Bangalore: 134-138.

Rashmi, N., Ranjitha, T., \& Sharath Chandra, S. P. 2019. Chromium and their derivatives causes physiological and biochemical modifications in diverse fish models: A review. 2019. Biomedical and Pharmacology Journal 12(4): 2049-2053.

Rotruck, J. T., Pope, A. L., Ganther, H. E., Swanson, A. B., Hafeman, D. G., \& Hoekstra, W. 1973. Selenium: biochemical role as a component of glutathione peroxidase. Science 179(4073): 588-90.

Saravanan, M., Karthika S., Malarvizhi, A., \& Ramesh, M. 2011a. Ecotoxicological impacts of clofibric acid and diclofenac in common carp (Cyprinus carpio) fingerlings: hematological, biochemical, ionoregulatory and enzymological responses. Journal of Hazardous Materials 15: 188-94.

Saravanan, M., Kumar, K.P., \& Ramesh, M. 2011b. Haematological and biochemical responses of freshwater teleost fish Cyprinus carpio (Actinopterygii: Cypriniformes) during acute and chronic sublethal exposure to lindane. Pesticide Biochemistry and Physiology 31: 206-11.

Seth, N. \& Saxena, K.K. 2003. Hematological responses in a freshwater fish Channa punctatus due to fenvalerate. Bulletin of Environmental Contamination and Toxicology 71: 1192-9.

Sharath Chandra, S. P. \& Sukumaran, S. 2020. Magnesium chloride impairs physio-biochemical and neurochemical responses in Cirrbinus mrigala (Hamilton, 1822) upon short term exposure. Biointerface Research in Applied Chemistry 10(1): 4934-8.

Shaw, B. J. \& Handy, R. D. 2011.Physiological effects of nanoparticles on fish: a comparison of nanometals versus metal ions. Environment International 37(6): 1083-97.

Wood, C. M., Hogstrand, C., Galvez, F., \& Munger, R. S. 1996. The physiology of waterborne silver toxicity in freshwater rainbow trout (Oncorbynchus mykiss). The effects of ionic $\mathrm{Ag}^{+}$. Aquatic Toxicology 35: 93-109. 